\title{
Caos e demonismo em O Diabo Mesquinho, DE Fiódor Sologub
}

Daniela Mountian'

ABstract: This articles aims to reflect on the use of literary archetypes in the Fiodor Sologub's novel The Petty Demon, highlighting the insertion of the myth of the creation in the structure of his work. When associating the evilness presented in the work to the original chaos, the novel inserts itself in the particular and powerful tradition of the Russian prose, inaugurating it and breaking it at the same time.

KeYwords: Russian symbolism, Literary archetypes, Anti-hero.

\section{Notas do simbolismo russo}

Uma questão levantada quando nos deparamos com O Diabo Mesquinho (Miélki Biés), romance do poeta, escritor e dramaturgo simbolista Fiódor Sologub (1863-1927), é como a obra se relaciona com os grandes romances naturalistas do século XIX - e em que medida foi precursora. Vale lembrar que o simbolismo russo não era dado a grandes romances, aliás, como se deu em toda parte. Miélki Biés foi escrito numa época em que o conto e a novela e sobretudo a poesia ganham destaque entre os literatos. Dentro dessa corrente, além de O Diabo Mesquinho, finalizado em 1902, podemos destacar talvez Petersburgo (1916), de Andrei Biély (1880-1934), e Asas (1906), de Mikhail

1 Desenvolve sua pesquisa de mestrado na área de Literatura e Cultura Russa do Departamento de Letras Orientais (FFLCH/USP). 
Kuzmín (1875-1936), como os romances mais representativos em questões de estética e literatura.

O movimento simbolista na Rússia, centrado no primeiro decênio do século XX, além de ter sido responsável por uma grande retomada no campo da poesia, fomentou um renascimento cultural em todos os sentidos, mudando os valores e os costumes. A concepção de vida se transforma no início do século - os simbolistas passam a viver como se a vida fosse uma extensão natural da arte. O poeta Vladisláv Khodassiévitch (1886-1939)² descreveu toda essa ambiência, da qual fizerem parte - além de grandes poetas e escritores como Aleksándr Blok (1880-1921), Andrei Biély, Fiódor Sologub e Valiéri Briussóv (1873-1924) -, personalidades ímpares que, mesmo. não deixando uma obra tão significativa, representavam em sua pessoa o hiperbólico mundo simbolista. É o caso, por exemplo, da escritora Nina Petróvskaia, que acabou se suicidando num pequeno hotel de Paris no ano de 1928. O caráter depressivo e intenso e os tormentos por que passou nas relações com Biély e depois com Briussóv fizeram de Nina uma das figuras lendárias entre os simbolistas, que viviam e criavam por entre esses destinos melancólicos.

Outro fato marcante dessa virada de século foi a presença de uma produção profícua de textos sobre arte e estética - o que representou uma grande abertura para as vanguardas que estavam por vir. Os simbolistas idealizavam, em geral, a noção de uma arte indivisível, sem fronteiras, da síntese das artes, encontrando correspondências entre todas as expressões artísticas. Acima de tudo, eles escreveram sobre a arte simbolista, sistematizando suas aspirações e manifestos em periódicos como A Balança (1904), Apolo (1909) e Mensageiros do Norte. Nessa época, diversos grupos se formaram, dos quais participavam poetas, teóricos, filosofos, pintores, atores, compositores etc. Temos, por exemplo, o famoso círculo de Dmítri Merejkóvski (1866-1941), frequentado por Nikolai Berdiáev (1874-1948), filósofo bastante importante para o movimento e seguidor de Vladímir Solovióv (1853-1900). Fiódor Sologub também mantinha um grupo em sua casa, "O Domingo" (Voskressiénie).

\footnotetext{
2 KHODASSIEVITCH, V. F. Nekrópol. Paris, 1976.
} 
Até então, considerando-se a ênfase dada à poesia e à "arte total" e o fato de o movimento ter propiciado mudanças de costumes e uma renovação cultural ampla, pode-se até estabelecer alguma comunicação com o simbolismo europeu, sobretudo com o francês. O que, no entanto, é normalmente apontado como o ponto crucial de diferença entre o simbolismo francês e o russo é o fato de que na Rússia simbolista a arte era vivida como um ato de fé, como uma experiência mística e principalmente filosófica, tendo como referência, não única mas norteadora, Vladímir Solovióv, que, embora ainda centrado nos preceitos da ortodoxia eclesiástica, é considerado o fundador da moderna filosofia russa. Solovióv deu também os primeiros passos para os estudos de estética na Rússia.

Solovióv percebia um mundo ambivalente, formado de elementos essencialmente antagônicos, como céu e terra, matéria e espírito, ideal e real, sendo que a missão do homem seria penetrar nesse antagonismo, buscando uma unidade entre o material e o imaterial. $\mathrm{O}$ caminho para alcançar esse elo seria dado pela arte, vinculada ao amor, já que este estaria nutrido de um potencial criativo e de renovação. Nessa fusão de mundos, na busca pela unidade, fica patente a transposição de ideais do cristianismo ao plano da estética.

Solovióv defendia também a ideia de um amor não ligado à reprodução (contrariando neste ponto os preceitos ortodoxos), um amor não fisicamente consumado, espiritual, particular, elevado, ligado à caridade e à compaixão (a noção de belo estava relacionada com a de compaixão) - a imagem de sofia, como eterna feminilidade virginal e sabedoria, foi muito revisitada. Esse amor nasceria da síntese entre o masculino e o feminino, da volta para um hermafroditismo divino e original. No entanto, o conceito deste hermafroditismo, como salienta Olga Matich, ${ }^{3}$ é ambíguo, porque implica obrigatoriamente uma desintegração - a consumação da paixão culminaria na destruição -, por isso a noção defendida pelo filósofo estaria mais próxima da androginia. Na realidade, nesta concepção de mundo, a unidade só poderia existir no plano da

MATICH, Olga. Symbolist Meaning of Love. Creation Life, the aesthetic utopia of Russian Modernism. Palo Alto: Stanford University Press, 1994. 
forma, da estética, sendo que o novo homem e o novo mundo seriam uma realização futura.

Todas essas noções, aqui apenas brevemente mencionadas, foram muito caras a poetas e escritores como Merejkóvski, Zinaida Híppius (1869-1945), Blok, Sologub, entre outros, mas aplicadas de formas muito diferentes. No caso de Blok e Sologub, houve a retomada de Solovióv pela concepção idealizada de amor, associada à imagem de sofia. O escritor Evguéni Zamiátin ${ }^{4}$ (1884-1937), grande entusiasta da obra de Sologub, coloca-o certeiramente ao lado de Dom Quixote, com a diferença de que aquele teria, em um amor impiedoso, esfaqueado suas protagonistas para que elas pudessem abandonar o mundo antes de ver a transformação inevitável de Dulcineia em Aldonça.

Fiódor Sologub, antes um professor de matemática, teve uma vasta carreira literária. Escreveu inúmeras poesias, romances, como Sonhos maus (Tiajolyie Sni, 1895) e a trilogia A lenda criada (Tvorimaia legenda, 19071914), peças de teatro, como O triunfo da morte (1907), ensaios e contos, como Luz e Sombras, Beleza, Na multidão e O arco. Suas Obras reunidas, publicadas em Petersburgo pela Editora Sírin (1913-1914), constituem 20 volumes, que foram ainda complementados com seus escritos posteriores.

\section{Um romance de transição}

O romance $O$ Diabo Mesquinho conta as peripécias de Ardalión Boríssytch Peredónov, um professor do ginásio de uma pequena província russa do fim do século XIX, que busca uma esposa para alcançar o sonhado posto de inspetor escolar. Numa série de intrigas e confusões, alimentadas por seus incorrigíveis circunvizinhos, o maldoso Peredónov passa a ser assaltado por estranhas alucinações, como a nedotykomka, que culminam num inexorável processo de loucura. Num enredo paralelo, mas que se mistura às diversas tramas e intrigas, temos o caso de amor da alegre Ludmila e o belo ginasiano Sacha, que conhece com ela as marcas ambíguas dos seus primeiros desejos.

4 ZAMIÁTIN, Evguéni. Lilsu (l'aces). Nova lorcue, 1955. 
Há um fato interessante no que concerne à produção de $O$ Diabo Mesquinho. A obra foi escrita durante dez anos, de 1892 a 1902, e começou a ser publicada, em série, na revista Questões da Vida, editada por Merejkóvski e Híppius. No entanto, a revista fechou antes de o romance terminar de sair, e ele acabou sendo editado integralmente apenas em 1907 pela editora Chipóvnik ${ }^{5}$ (São Petersburgo). Durante esse período, de 1892 a 1907, o cenário russo mudou completamente: o público que recebeu Miélki Biés já havia presenciado a revolução de 1905 e a humilhante derrota que a Rússia sofreu na guerra contra o Japão, e o simbolismo, que estava apenas se formando quando Sologub começou a escrever sua obra-prima, entrava agora numa fase muito mais hermética e metafísica. Fiódor Sologub era mesmo um homem de dois séculos, e seu legado mais importante, Miélki Biés, representa exatamente isso: o romance, que de certa forma se diferencia das outras obras do autor, pode ser lido como um divisor de águas da prosa russa, estabelecendo uma abertura, uma ponte entre os grandes romances realistas ${ }^{6}$ do século XIX e as vanguardas do início do século XX, como aponta Viktor Eroféiev.

Eroféiev, no capítulo intitulado "No limiar do realismo", notou que nessa abertura houve um uso paródico de diversos procedimentos e motivos do século XIX, e isso pode ser percebido em várias camadas de leitura. $\mathrm{O}$ autor estabelece inúmeros parentescos, no texto e no subtexto, entre Miélki Biés e obras que o precederam. No texto, por comparações objetivas no enredo, como, por exemplo, no caso de Almas Mortas, ${ }^{8}$ aproximando a peregrinação

5 A editora Chipóvnik (Rosa silvestre) publicou muitos autores simbolistas, como F. Sologub, A. Biély e Aleksei Remízov (1877-1957). Fechou em 1922.

6 Apesar de os termos "realismo" e "naturalismo" não terem sido empregados pela crítica russa na época, neste artigo ele são usados por sua acepção já consagrada entre nós. Realismo, entendido como um método de representação da realidade, e naturalismo, como a escola que utiliza esse método de modo preponderante.

7 EROFÉEEV, Viktor. V labirinte prokliatykh voprossov. (No labirinto das perguntas malditas). Moscou, Soiúz fotokhudójnikov Rossii (União dos fotógrafos da Rússia), 1996.

8 Miélkii Biés estabelece diálogos importantes com outros autores, como A. Púchkin (1799-1837) e F. Dostoiévski (1821-1881), sempre numa referência direta. Peredónov reúne elementos dos mais notáveis anti-heróis da literatura russa, como, por exemplo, do obsessivo Hermann, de A Dama de Espadas, conto de Púchkin de 1833. 
de Thitchios" na compra das almas mortas (os servos eram chamados de

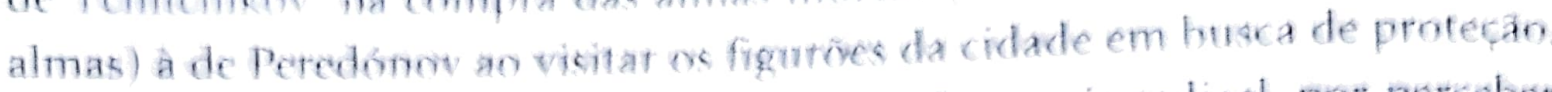
No subtexto, e talver encontremos aqui a quethra mais padical. por perceber um tompimento com a cenca no que chamow de "filosofia da esperanca". Os conceitos de heleza. hondade e verdade cwias ligacoues foram perseguidas

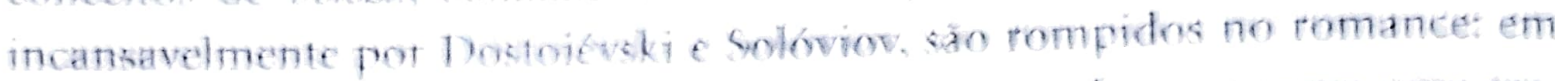

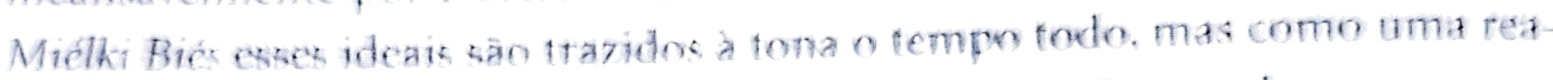
lidade intangivel, num procesoo de desencantamento do mundo.

Diana Greene tambem concentra sua analise em mostrat como O Diabo Mesquintio subverte os modelos natutalistas quanto a forma. Grosso modo, dis afurma que a composicào se afasta da tradicäo oilocentista. porque o enredo e pelo fato de as personagens estao subjugados pelo tempo espaço e. sobretudo, pela narsacao. Todos os clementos do nomance sâo conduzidos pelo nar tador para um ponto - para o caos da personagem de Ardalion Peretonov:

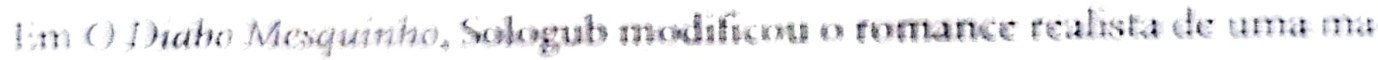

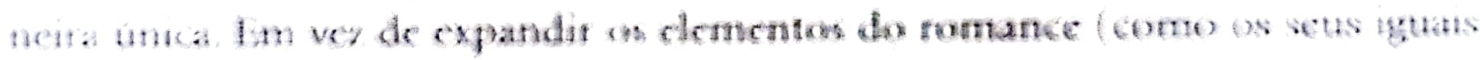

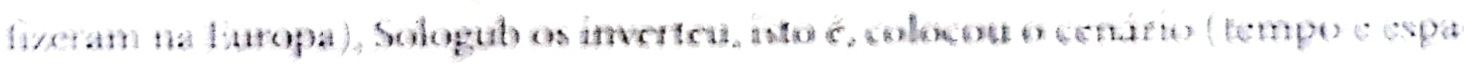

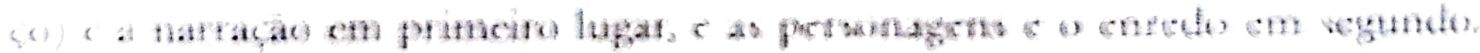
(ARINA I480, D, 51 )

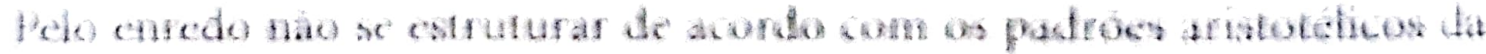

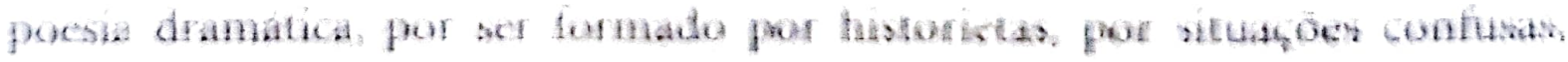

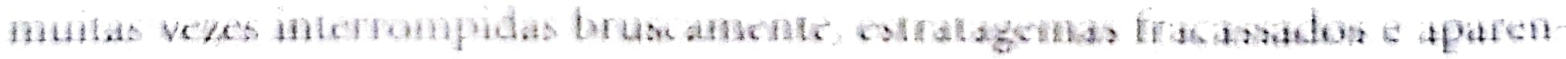

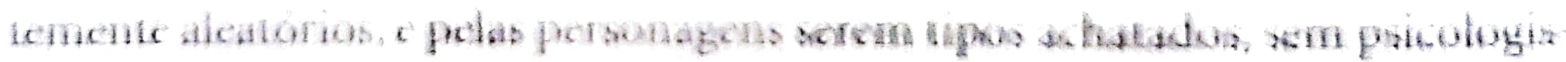

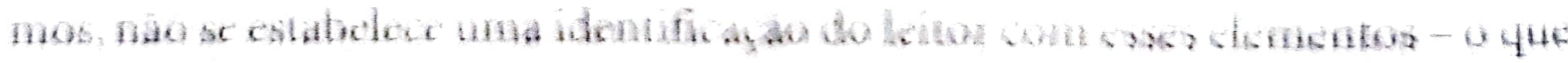

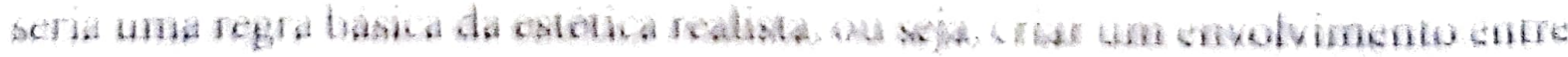

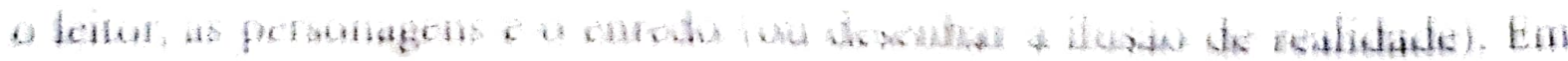

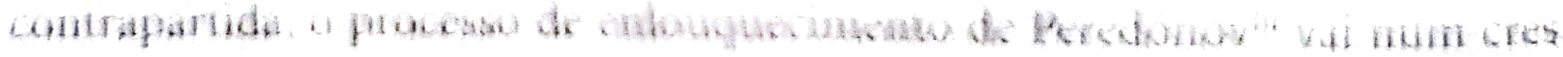

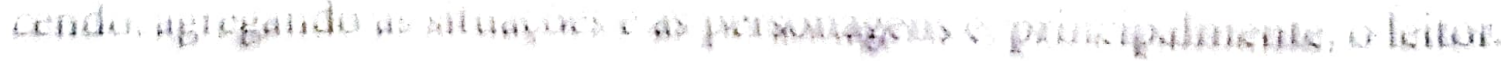

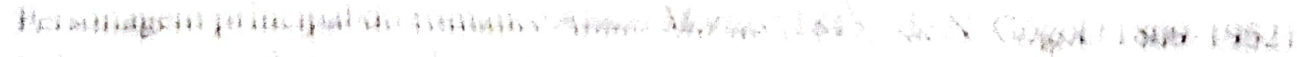

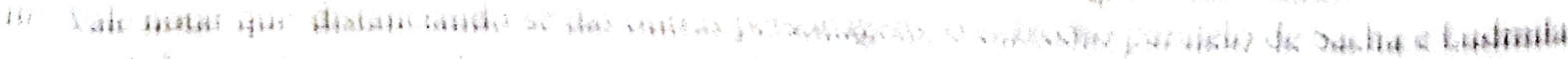

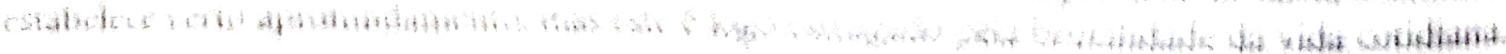


A narração do romance "absorve o caos em si", como aponta Eroféiev, delineando-se a grande ruptura com o narrador naturalista. De um lado, o narrador de Miélki Biés desempenha seu papel tradicional - com uma voz onisciente rege o espaço entre o leitor e as personagens -, mas, de outro, legitima o enraizamento da loucura de Peredónov. Essa contaminação é notada em vários pontos, como, por exemplo, na temporalidade inconstante - ora o tempo é descrito com precisão, "de terça-feira seguinte em diante", ora fica completamente vago, acompanhando a instabilidade de Peredónov - ou nos elementos que irão povoar suas alucinações, apresentados desde o início exatamente como ele os verá depois, já no ápice da sua loucura. Vejamos a descrição de Volódin, o tolo amigo do professor:

Com uma risada alegre e barulhenta, entrou Pável Vassílievitch Volódin, um jovem, no rosto e no jeito, surpreendentemente parecido com um carneiro: cabelos encaracolados como pelo de carneiro, olhos esbugalhados e sonsos - todo ele como um alegre carneirinho -, um jovem abobalhado. Volódin era marceneiro, estudara numa escola técnica e agora ensinava o mister na escola técnica do município. (SOLOGUB, 2008, p. 36)

Peredónov, já em processo de delírio, depara com seu amigo num cruzamento:

Na rua, tudo parecia hostil e sinistro aos olhos de Peredónov. No cruzamento, um carneiro o fitava com olhar inexpressivo. Um carneiro tão parecido com Volódin que Peredónov levou um susto e pensou que talvez Volódin tivesse se transformado em carneiro para espioná-lo. (SOLOGUB, 2008, p. 240)

E Peredónov, já no auge do seu enlouquecimento:

Peredónov afundava-se cada vez mais na loucura. Continuava a escrever denúncias contra as cartas do baralho. E agora também contra a nedotykomka, o

Sacha, acima de tudo, funciona como oposição a Peredónov. Aquele, no fìm, torna-se o grande impostor, enquanto Peredónov, o grande trapaceado. 
carneiro - que se fazia passar por Volódin e pretendia assumir um cargo importante, mesmo sendo apenas um carneiro - e contra os cortadores de lenha - que haviam abatido todas as bétulas, de modo que não havia mais como tomar banho a vapor, além de ter ficado difícil educar as crianças; deixaram apenas os álamos, mas quem precisa de álamos? (SOLOGUB, 2008, p. 338)

Não é possível afirmar que se trata de uma narrativa moderna, na qual muitas vezes o leitor não sabe absolutamente onde está e no que confiar, mas as funções da narração em Miélki Biés com certeza modificam as convenções e constituem um dos elementos que coloca a obra num limiar: "Enquanto personagem, enredo e cenário, a narrativa de $O$ Diabo Mesquinho não é realista nem modernista."11

É também pela narração que O Diabo Mesquinho se afasta de um romance simbolista, do ponto de vista de sua composição, apesar de trazer várias idiossincrasias do movimento, como a percepção místico-filosófica de um mundo dual, no qual o real está permeado pela banalidade, pelo grotesco e pelo supérfluo, sob a égide da figura do Dragão, em contraposição a um universo ideal e bucólico, que se realizaria por meio da criação. ${ }^{12}$

Não é tarefa simples nem completamente objetiva definir se um romance é ou não simbolista em sua estrutura, mas podemos tomar como ponto de partida a presença de uma relação inextricável entre o autor, a narração e o enredo, num jogo de correspondências no qual o leitor é quase um intruso. É a "contaminação entre arte e vida", 13 conforme o que os simbolistas pensavam, tendo Nietzsche como base, pelo menos quanto à ideia da arte como um ato de criação superior. Esse sistema hermético não define a estrutura de $O$ Diabo

11 GREENE, Diana. Insidious Intent, an interpretation of Fedor Sologub's The Petty Demon. Bloomington, 1986, p 97.

12 Em O Diabo Mesquinho, o mundo ideal, embebido em inocência, beleza e arte, normalmente associado por Sologub à figura da criança, quase não tem espaço. Diferentemente das outras obras do autor, aqui a narraçāo impossibilita a presença de quaisquer elementos positivos, sendo a representação do mundano e do cotidiano vulgar, em oposição a um ideal perdido.

13 NIVAT, George. O simbolismo russo em busca do paraíso original. Tipologia do simbolismo nas culturas russa e ocidental. São Paulo, 2005. 
Mesquinho, uma vez que se estabelecem relações entre o leitor, a narração e o protagonista - um romance simbolista constituiria um sistema fechado de contaminaçoes. A introdução ao romance Petersburgo, de Andrei Biély, feita pelos editores americanos Robert A. Maguire e John E. Malmstad, dá o contraponto:

Não há pensamentos ou ações privados em Petersburgo; todos são reflexos de realidades maiores, que, por sua vez, são vivenciadas por todas as personagens... O mundo do romance é, em última análise, um mundo fechado no qual todos os pontos estão ligados. (GREENE, 1986, p. 128)

De fato, o romance de Sologub rompe com a escola naturalista e utiliza métodos realistas com ironia e desprendimento. A obra, com reminiscências tomadas parodicamente, ocupa uma posição singular na literatura - não se encaixa exatamente em nenhuma escola ou método de representação, apesar de receber influências diversas. É preciso destacar, contudo, que é praticamente impossível achar o naturalismo na sua forma pura, sobretudo no caso da literatura russa, que já nasce na paródia. ${ }^{14} \mathrm{~A}$ desorientação do leitor pela narração, assim como a quebra dos padrões de verossimilhança seguidos pelos naturalistas, pelo menos nos moldes europeus, foi delineada também por escritores como Gógol e Dostoiévski. Mas, de todo modo, eles foram grandes inovadores da língua russa.

\section{Caos e demonismo em $O$ Diabo Mesquinho}

Quando Fiódor Sologub criou seu romance seminal, as grandes obras do "século de ouro" já haviam sido escritas, Dostoiévski já havia morrido, Tolstói já renegava suas grandes obras-primas, Tchékhov já produzia suas entrelinhas.

14 Desde Púchkin, a paródia se revela elemento essencial às letras russas - em sua obra há utilizaçio de arquétipos e motivos arquetípicos do classicismo e do romantismo, mistura de gênetos e tons, presença epistolar e de epígrafes, muitas věes desconectadas do corpo da obra. O procedimento paródico não necessariamente envolve a ironia jocosa, mas sempre estabelece um diálogo intertextual, tal qual é entendido por autores como Linha Hutcheon e Haroldo de Campos. 
Surgir nesse momento uma composição como Miélki Biés, baseada em personagens de marcas arquetípicas tão exacerbadas, conduzidas para um processo de enlouquecimento tão obsessivo como o de Peredónov, só poderia definir um outro tipo de articulação com o gênero romanesco e com o mundo. Trazendo temas já consagrados pela literatura russa, a obra lida parodicamente com arquétipss de referências antigas. No final das contas, temos um anti-herói, um trickster, travando verdadeiros duelos contra bruxas, feiticeiras e criaturas disformes - no auge da loucura de Peredónov, a narração nos faz entrar em contato com imagens míticas e com a ambivalência primordial do mundo.

Não é novidade entre os russos a inserção do mito da criação - das variantes dessa temática e sobretudo da sua relação com o herói - como alicerce da narrativa, o que pode até ser uma chave explicativa para a presença tão marcante do tema do caos e do demonismo na sua literatura. Na Rússia, muito mais intensamente que na Europa, a questão da concepção do mundo, do mito básico (caos versus cosmos), recebeu sempre uma atenção especial dos escritores e artistas, "numa abrangência comparável à dimensão mitológica dos arquétipos". ${ }^{15}$ Para entender melhor esse tipo de articulação na literatura, é preciso antes refletir sobre o processo de transformação do herói e do anti-herói ao longo dos séculos, questão fundamental ao trabalho de Eleazar Meletínski.

Um ponto fundamental ao qual Meletínski se reporta no que se refere à construção do anti-herói, do trickster, é que esse arquétipo literário ${ }^{16}$ aparece já nos mitos de criação - o anti-herói, o impostor, nasce junto com o herói cultural:

Em sua forma clássica, o trickster é gêmeo do herói cultural, sendo-lhe oposto não como o princípio inconsciente se opõe ao consciente, mas antes como o ingênuo, o maldoso, o destrutivo se opõe ao sábio e ao criativo. (MELETINSKKI, 2002, p. 97)

MELETINSKI, E. M. Os arquétipos literários. São Paulo, 2002, p. 171.

Meletínski teve o cuidado de demarcar um espaço entre sua concepçào de arquétipo e à de outros autores, como a de Jung e seus discípulos. Em linhas gerais, o autor russo sai da esfera estrita do rito: "Na verdade o ritual é o aspecto 'formal' e o mito, o aspecto 'conteudístico' do mesmo fenomeno." Ibidem, p. 43. 
Ao construit o arquétipo de heró cultural, Melefínski liga o mais arcaico dos herois, o heroi mitico, a luta "contra as forcas demónicas do caos", integrando-o ao mito básico da criação. Nesse momento, o herói ainda faria parte do coletivo, ele representava o colctivo - mesmo tendo um papel de destaque (a personalizacào do herói só se dá mais fardiamente). A funcăo básica do heroi antigo estava centrada na obtencão de objetos culturais fogo. luz, instrumentos de trabalho), na construça do mundo. muitas vezes auxiliado por divindades. E aqui o autor usa a imagem de Prometeu. "que näo apenas da o fogo aos homens, mas sofre por eles a vingança de Zeus".

Desse heró, ainda com uma função provedora. Foi-se consolidindo de maneira mais demarcada o herói cultural de formaçao. aquele que de modo explicito "representava as forças do cosmos co defendia dos monstros demoniacos que personificavam o caos". Entre o mito e o cpos, a luta desse herof contra dragoes e serpentes, 18 "as figuras demónicas arquetipicas mais estavers", configura se um motivo fundamental.

la nos heróis épicos, revela-se a questao da defesa dit pateia. e os monstros estariam personificados nos forasteiros, nato mais em criaturas demoniacas, Os herois épicos atuavam como integrantes de uma tribo. Quef dizer. alem da obtençâo de objetos culturais, da luta contra as forças demoniacas do caos. entra a questäo da defesa (ligada a uma crenca) do coletivo, 10 qual o herot evta intrinsecanente ligado. Nesse momento, inserem- os diverson rituato de incaça, em que há um isolamento temporario do herot, que pana por inumeras provacoes. De forma esbocada, achamos a base do herót dos contos marave linosos (diferente do heroi dos contos de magia) e dos romanses de formatio

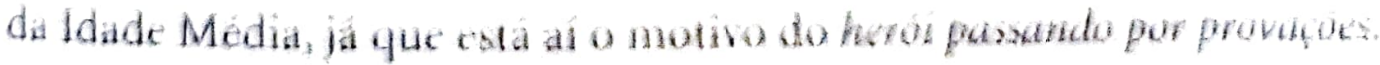

Hiden, p. Ak

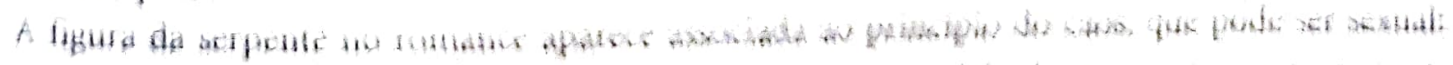

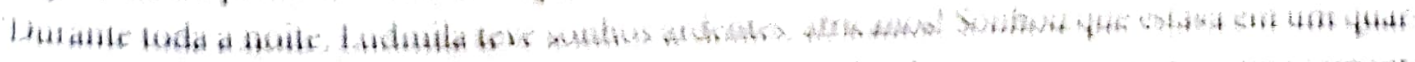

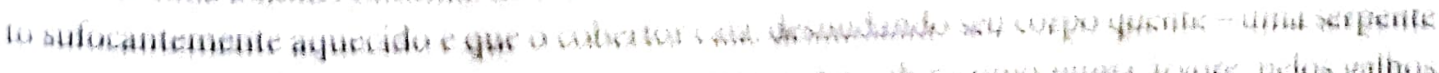

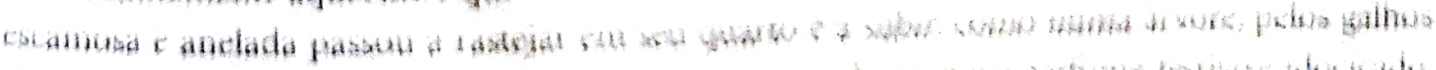
de suas lindas peritas nuas

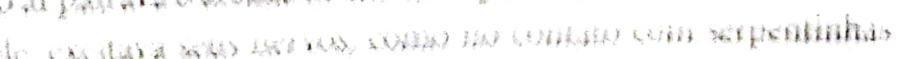

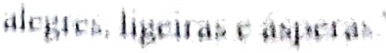


Diferentemente do epos, o herói mitico está proximo dos deuses, cuja grande qualidade está relacionada com sua ascendência divina - nota-se que csse heró nàn é imottal, e nunca poderia sê lo, ele tem uma origem mista, nascendo muitas vezes de um pedaço do corpo divino, como Dionísio, concebido da coxa de Zeus. O herói épico, por sua vez, não revela seu heroísmo por uma ascendencia divina, mas atua por meio da ousadia, da coragem e da força fisica, com um caráter obstinado, que cada vez mais se desquita do coletivo de onde saiu - surge a questão da personalização do herói e da criação de um mundo interior (os heróis antigos não tinham pensamentos privados).

E, portanto, na narrativa épica que Meletínski localiza o arquetipo de heró propriamente dito, uma vez que no mito o herói ainda não tem suas caracteristicas nitidamente demarcadas: "No mito heróico, o caráter épico é apenas esbocado, enquanto na épica ele é completamente acabado, sendo que por isso nele se forma este importantíssimo elemento que ê a imagem arquetipica do herói"."

Os arquétipos e temas arquetipicos se cruzaram de diversas maneiras e se transformaram ao longo do tempo. Grosso modo, o herôi passou por um processo de personalizaçâo e de diluição de seus traços arquuetipicos. No romance de cavalaria há a junçåo do arquêtipo do herói épico com os ideais romànticos e cavalheirescos, O herói agora é movido por paixões pessoais, que representam o caos social - ele se torna um elemento que potencializa os problemas da sociedade que o cerca. Na Renascença, hâ uma união ainda maior dos ideais cavalheirescos e épicos. Nos romances naturalistas do século XIX, ha um processo de desmistificaçào do herói. I na literatura moderna do século $X X$, em geral, reina a "plena deseroicizaçao".

Como o herói, anti herói também sofreu uma transformaça com 0 Passar dos seculos. Como oposiçao ao heroi cultural mitico, o trickster, o impostor, untiza ae da astucia para alcangar os antefatos "culturais" pequenas traquinagens para saciar a propria fome, momalmente. A dimensio travessa,

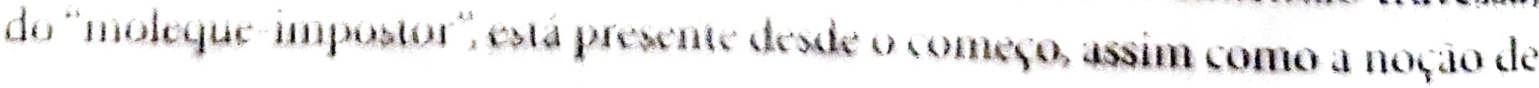

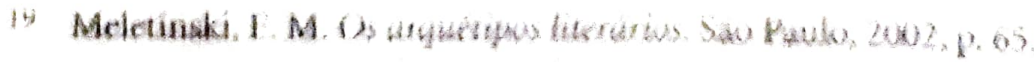


um ser marginal e antissocial, indo muitas vezes contra o clã ou a tribo. No entanto, a exacerbação das características egoístas acontece mais tarde.

Também no mito antigo já aparece esboçada a questão da duplicidade, uma vez que o trickster se afigura como a "variante negativa demônico-cômica" do herói mítico, noção relacionada com um "dualismo ético", Deus versus Diabo, e com a separação ainda demarcada entre "heroico e cômico". A exploração do duplo é depois fortemente retomada pelos românticos, ou ainda por autores como Doistoiévski, procedimento analisado por Bakhtin, tendo como base a literatura carnavalizada. Quanto à dimensão demoníaca do trickster, ela é suavizada com o tempo, como nos contos picarescos, em favor de outras características, que são ressaltadas.

O pícaro espanhol retoma o trickster arcaico, incluindo outras duas dimensões: a do bufão e a do simplório, sendo que essas três categorias (impostor, bufão e simplório) são alternadas: podemos ter um bufão disfarçado de simplório, ou, mais raramente, um simplório disfarçado de bufão, como no caso de Peredónov, fazendo grandes e pequenas travessuras.

Desse modo, numa primeira leitura, Peredónov e Volódin trazem o mito arcaico do trickster atualizado, ou seja, possuem elementos picarescos. Temos Peredónov, um simplório que se vê como bufão, para quem “(...) ser feliz significava não fazer nada e, fechando-se no seu mundo, satisfazer as próprias vísceras" ${ }^{20} \mathrm{Ou}$ como o trickster que fracassa em seus objetivos, o que também aparece no mito antigo. Na verdade, a audácia e a esperteza nunca poderiam caracterizar Ardalión Peredónov, pois ele era incapaz de obter sucesso de seus estratagemas, não tinha habilidades manuais nem esperteza e só conseguiia entender a realidade literalmente:

Prepoloviénskaia pegou um ovo.

- Que ovos bonitos - disse ela -, onde arrumaram?

Peredónov disse:

- Que nada! Na nossa propriedade, a galinha do meu pai botava dois ovos grandes por dia, e o ano inteiro. 
- Grande coisa - respondeu Prepolovienskaia -, achou com que se gabar! Na nossa aldcia, havia uma galinha que botava dois ovos por dia e uma colherada de mantciga.

- Sim, sim, c a nossa também - dissc Peredónov não notando a brincadeira. - Se as outras fazcm, cla também fazia. A nossa era uma galinha extraordinária. (SOLOGUB, 2008, p. 73)

Já Volódin, desempenhando o papel do trickster simplório, aproveita qualquer oportunidade para encher a pança:

Por acaso ela havia comprado o caviar a Volódin? Com o pretexto de servir as damas, ela afastou dele tudo o que havia de melhor. Mas ele não desanimava e satisfazia-se com o que sobrava. Já tinha conseguido comer muita coisa boa no começo, e agora tanto fazia. (SOLOGUB, 2008, p. 279)

Ou numa atuação conjunta, beirando o ridículo, retomando o motivo arquetípico da presença de uma dupla no enredo, normalmente formada de um "sábio" e um “idiota":

- O que o senhor está levando, Ardalión Boríssytch? - perguntou Prepoloviénskaia.

- Livros severamente proibidos - respondeu Peredónov enquanto andava. - Vão me denunciar, caso descubram.

Na sala, Peredónov agachou-se diante da estufa, atirou os livros sobre uma chapa de ferro (Volódin fez o mesmo) e começou, com esforço, a enfiar um livro atrás do outro pela estreita abertura da estufa. Volódin, agachado ao seu lado e um pouco recuado, ia the passando os livros mantendo uma expressão compenetrada e solidária no rosto de carneiro - os lábios salientes, para se dar importancia, e a testa proeminente, que baixava por excesso de inteligência. Varvara espiava através da porta. Rindo, ela falou:

- Lá vão eles bancar os palhaços. (SOLOGUB, 2008, p, 77)

Esse procedimento cômico foi empregado inúmeras vezes na literatura, como em Dom Quixote, no qual Sacho Pança dava o contraponto ao cavaleiro 
de triste figura. Em () Diabo Mesquinho, isso é reiterado por meio de outras personagens, comno Varvata, a amante do professor, e fruchina, uma viuva desleixada e com quem aquela tramava os mais tolos planos para agarrar Peredonov em um casamento.

Em linhas gerais, todas as personagens do romance apresentam caracteris. ticas picatescas, do trickster atualizado, sempte num movimento pendular. en tre o bufáo e o simplório - apesar de Volódin quase nào variar. desempenhando basicamente o papel de simplótio (afinal, cle cra apenas um carneiro que seria sacrificado). Essa nocào de "impostura geral" ć tratada por Meletinski náo mais pelo arquetipo de trickstet, mas na linha do romance tricksteriomo, no qual hat uma transformacăo do simplório $\mathrm{em}$ bufáo, $\mathrm{c}$ do bufáo $\mathrm{em}$ impostor.

No caso de Miélki Bićs, apesar de reinar a impostura, esse procedimento so pode ser rigorosamente identificado em Sacha, que chega como um simplorto, um rapaz modesto e educado, e termina como um impostor. enganando a ct dade inteira e climinando a única fresta aberta no romance pafa a peesença de elementos desquitados da trapaça e do grotesco.

Eis Alcksándr Pýlnikov, o Sacha, logo ao chegar a cidade, quando wagto por Peredonov a entregaf seus colegas:

- Então, Sáchenka, ferou direitinho a Deus hoje?

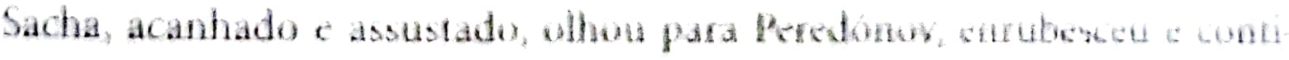
nuou calado.

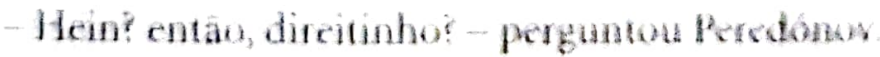

- Dircitinho-disse Sacha por fim

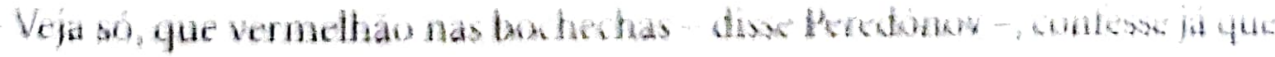
etuma menina! Uma menima espera!

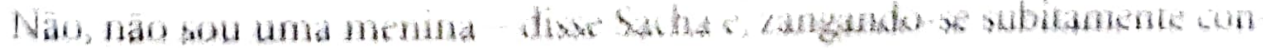

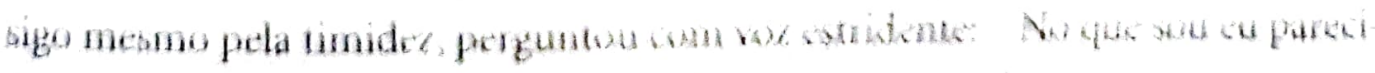

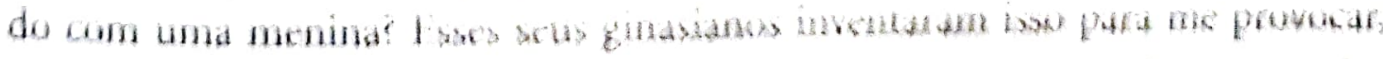

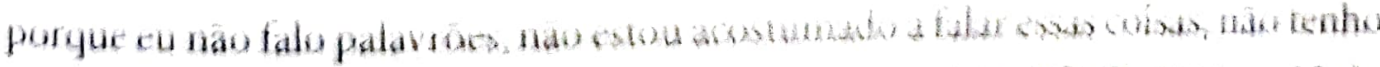

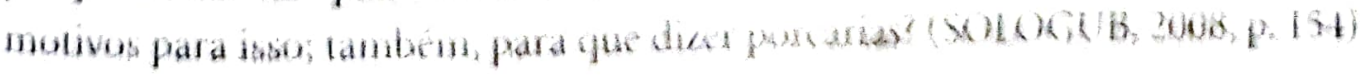

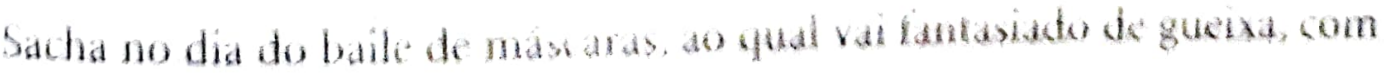
um leque e tamancos de madeud: 
No dia do baile, Sacha teve a impressão de que não conseguiria ir. Tinha medo. Apenas uma coisa o impedia de desistir: a roupa pronta na casa dos Rutílov. Ficaria lá jogada às traças? Todos os sonhos e o trabalho teriam sido em vão? E com certeza Ludmílotchka choraria. Não, era preciso ir.

Só mesmo o costume de dissimular, adquirido nas últimas semanas, ajudou Sacha a não revelar à Kokóvkina a sua agitação. (SOLOGUB, 2008, p. 350)

Sacha durante o baile, já como gueixa, com movimentos sedutores e maliciosos:

Era preciso agradecer - pensou ele. Assim exigiam as velhas maneiras de um menino educado. A gueixa se inclinou, disse algo incompreensível, deu uma risadinha e levantou os dedinhos, e mais uma vez se elevou uma gritaria frenética na sala, ouviram-se assobios e palavrões. Todos se precipitaram para cima dela. (SOLOGUB, 2008, p. 363)

Se de um lado podemos afirmar que Miélki Biés se encaixa na linha do romance tricksteriano, com o uso de arquétipos picarescos, de outro, é na loucura de Ardalión Boríssytch Peredónov que se define a camada primordial do romance. Peredónov não pode ser lido apenas como um impostor picaresco: conforme a sua loucura se aprofundava, ele se associa a outro aspecto do anti-herói, passando a lidar com forças demoníacas e a ser constrangido por desejos de destruição e morte. Ardalión Peredónov começa a corporificar o próprio caos e autoriza a inserção na obra do mito original e do trickster antigo, buscando sempre a desarmonia e lidando com os instintos mais primitivos e subterráneos do ser humano:

Um pavor insensato havia forjado nele a disposiçĩo para o crime, a imagem de um futuro assassinato, inconsciente, obscura e escondida nas regiōes inferiores de sua vida espiritual, uma irresistível comichão de matar; a condição primordial da maldade oprimia a sua vontade já depravada. Ainda aprisionada - muitas geraçôes jaziam no antigo Caim - essia disposição sattistazia-se em quebrar e estragar coisas, em cortá-las com o machado e a faca, em abater as árvores no jardim para que nenhum espião o espreitasse de lá. Na destruiçio das coisas, alegrava-se o 
antigo demonio, o espirito da confusào pré-historica, o antigo cans, enquanto os

olhos selvagens de um homem louco refletiam um pavor semelhante ans mons. truosos tormentos da agonia derradeira. (SOI.)( (UUB, 200)8, p. 315)

No entanto, paradoxalmente, Peredónov luta contra o caos que ele mesmo personifica. Lle luta contra a nedotykomka, ele luta contra o gato "gordo e feio". ele luta contra valetes $\mathrm{e}$ rainhas, ele luta c sofre. Há uma ambivaléncia presente em Peredónov que pode ser compreendida pelo fato de o anti-herói ser o "polo negativo" do herói cultural arcaico, uma variação de si mesmo, de um heró mítico que luta contra monstros diversos e forças ocultas da terra: " tricksters mitológicos muitas vezes guerreiam com o herói, mas ao mesmo tempo sâo seus irmãos (pertencem ao mesmo mundo 'próprio' ou chegam a ser até um segundo 'eu' do próprio herói)".21

Entre os inúmeros duelos travados por Peredónov, a nedotykomka fot a sua grande batalha, e ele criava os mais tolos planos para livrar-se dela, como cortar o vestido da amante, caso esta tivesse carregado o diabo no bolso. () termo nedotykomka é um neologismo do autor formado, como notou (iretene. pelos prefixos ne (nâo) e do (até) e o verbo tykat, que pode significar "fincar". "travar", "penetrar", ou seja, é uma criatura impenetrável, inalcançável. Na mesma direção, Margarita Pavlova liga o termo a nedotrugá, algo sensivel, im possível de tocar.

A nedotykomka, "suja, cinza e amorfa", é a propria representaça do caos original, usualmente identificado como algo disforme. Bla uma alucinatio individual, mas é alimentada pelo coletivo e passa a representá lo (it retaça dit nedotykmomka com as outras personagens é fortalecida pela narraça tumat vez que o demonismo, corporificado por Ardalión, nase também dos proprios

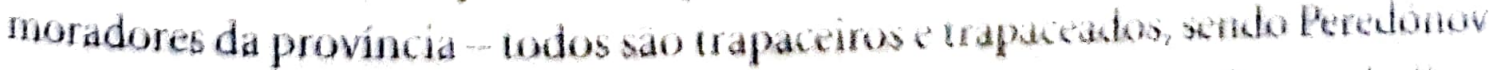
expressảo máxima dessa sociedade e vitiona do grands embuste do enredo.

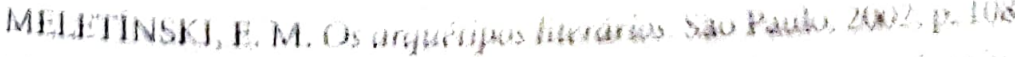

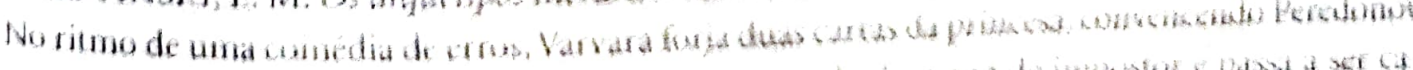

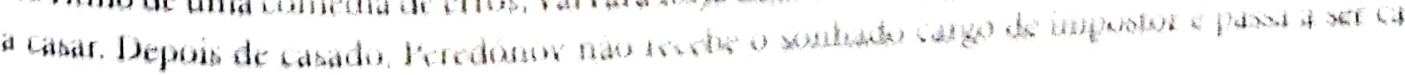
Goado pela cidade intera 
Outra possibilidade de leitura da nedolykomka está ligada ao caos sexual, que, na realidade, pode derivar do mesmo princípio do caos original. Como Bethea $^{23}$ notou, a aparição da nedotykomka está associada à de Sacha - a nedotykomka só começa a importunar Peredónov depois de ele ter visto aquele pela primeira vez, ajoelhado na igreja. Sacha desperta sensações contraditórias no sombrio professor, formando-se uma espécie de triângulo amoroso entre o jovem ginasiano, Ludmila, que passa a seduzi-lo como uma "pagã" grega, e Peredónov.

Bethea observa que, dentro do nome Pýlnikov, temos uma dupla referência - pyl significa "sujeira" e também funciona como partícula de raspylítel, "pulverizador", o instrumento que Ludmila usava para perfumá-lo e encantá-lo. Com efeito, a presença de Sacha traz uma dicotomia. Mal chegou à cidade, belo e jovem, de traços delicados, causou alarido. Logo se alastrou a notícia de que ele seria na realidade uma menina disfarçada de menino, situação que virou mais uma luta de Peredónov:

Mas era mesmo um menino? Talvez fossem duas pessoas numa só: irmão e irmã, sendo impossível distinguir um do outro. Ou talvez fosse capaz de se transformar de menino em menina. Afinal de contas, não era à toa que andava sempre tão limpinho - para se transformar, ele tinha que se banhar em águas mágicas, não havia outro jeito de fazer isso. E sempre emanava dele algum perfume.

- Com que o senhor se perfumou, Pýlnikov? - perguntou Peredónov. - Será que com sujeira? (SOLOGUB, 2008, p. 333)

Foram mencionadas algumas das referências que nos levam ao mito da criação, mas há diversas outras, como, por exemplo, a relação angustiante que Peredónov estabelece com a natureza, seus esconjuros, sua vontade de destruir, sujar e entortar tudo à sua volta etc. Em contato com o mito, a relação do caos com o demonísmo, elementos originalmente relacionados, é retomada com força. Uma lacuna se abre ao longo do romance, que chega à desintegração do indivíduo - afinal, o mundo moderno não comporta mais heróis míticos -, c

23 David M. Bethea. Sologub, Nabokov, and the Iimits of Decaldents Aesthetics. The Russian Re'view 63 (January 20(14): 48-62.1 awrence, 2004. 
audo culmina bruscamente no assassinato de Volodin. Peredónov, no ponto maximo de sua loucuta, sacrifica seu amigo, com uma adaga.

Finalmente, cliaram coragem e entraram - P'eredóncov estava sentado cabis haixo c balbuciava alguma coisa desconexa esem sentido. (SOTOC.UP, p. 324)

A rua ficou de pé

Com Miélki Bics, Fiódor Sologub se insere na poderosa e peculiar tradicao russa ao construit um diabo como protagonista. Em Peredonov, como Dostoievski disse sobre Memórias do Subsolo, também "estào reunidos todos os traços do anti-herói", inclusive, a luta contra o caos. Os elementos da com pocicao saltam aos olhos, numa estrutura paródica em diversos planos, le vando-nos ao caos originário das nossas visceras, de uma sociedade submersa na impostura e na escuridao. Destaca-se uma narrativa que deixa o leitor com um pé atrás, com elementos aparentemente aleatórios. mas perfeitamente atrelados ao caos e ao demonismo no qual Ardaliôn Perelonoy se afunda. Mais do que com tipos sociais, Sologub lida com arquetipos literartos para desenhar um mundo desencantado e sombrio, no qual nato ha mats espaco para a beleza, a bondade e a verdade.

A obra, radurida para diversas linguas, teve enorme repercusaa - muitos escreveram sobre Sologub, principalmente os stmbolistas, enter on quati a imagem do autor era emblenatica, sempre lembradosom seu pincene, as pernas cruzadas e o olhar ausente, como se o mundo au seu fotor of fatigatse ter rivelnente. A maioria tentou relacionálo com a personigem do protessor

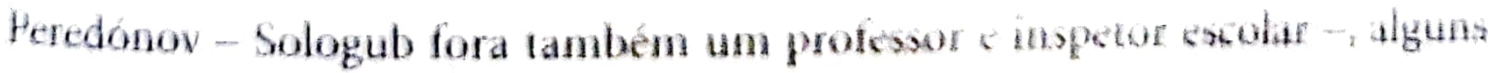

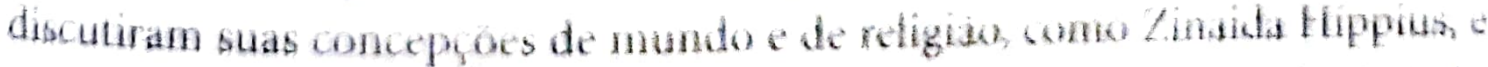

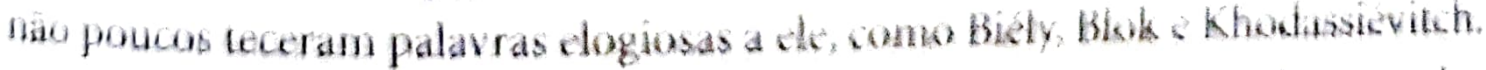

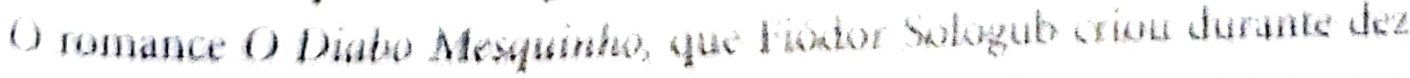

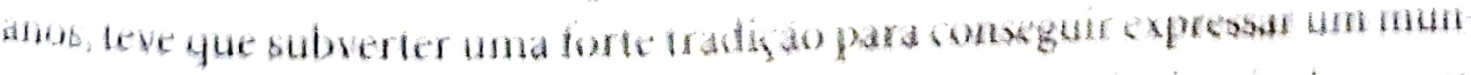

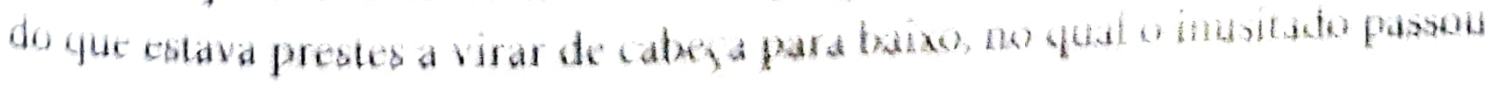
a ser a ordem do dia

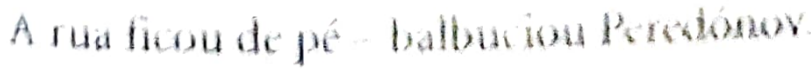




\section{Referências bibliográficas}

AN1DRADE, Homero de Freitas. Breves noçoes sobre o simbolismo na Rússia. Tipologia do simbolismo nas culturas russa e ocidental. São Paulo: Associação Editorial Humanitas, 2005.

AUERBACH, Erich. Mimcsis. São Paulo: Perspectiva, 2007.

BAKHTIN, Mikhail M. Problcmas da Poética de Dostoiévski. Rio de Janeiro: Forense Universitária, 2005.

BAKHTIN, Mikhail M. Questões de Literatura e de Estética. São Paulo: Hucitec, 1993.

BERLIN, Isaiah. Pensadores Russos. São Paulo: Companhia das Letras, 1988.

BERNARDINI, Aurora Fornoni. Questões de forma e modernidade em Gógol e Dostoiévski. A Questão da Modernidade. São Paulo: FFLCH/USP, 1993.

BETHEA, David M. Sologub, Nabokov, and The Limits of Decadents Aesthetics. The Russian Review 63 (January 2004): 48-62. Lawrence: Blackwell Publishing, 2004.

CAVALIERE, Arlete. A Magia das Máscaras. São Paulo: Edusp, 1990.

CAVALIERE, Arlete; VÁSSINA, Elena; SILVA, Noé (Org.). Tipologia do simbolismo nas culturas russa e ocidental. São Paulo: Associação Editorial Humanitas, 2005.

EROFEIEV, Viktor. Na grani razryva - 'Miélkii Biés' F. Sologuba i russkii realizm (No limiar da ruptura - O Diabo Mesquinho de F. Sologub e o realismo russo). V labirinte prokliaryk hoprossov (Nolabirinto das perguntas malditas). Moscou: Soiriz fotokhudojnikov Rossii (Uniāo dos fotógrafos da Rússia), 1996.

GREENE, Diana. Insidious Intent, an interpretation of Fedor Sologub's The Petty Dermon. Bloomington: Slavica Publishers, Inc, 1986.

GROSSMAN, J. D); PAPERNO, I (Org.). Creation life, the uesthetic utopia of Russian Modernism. Palo Alto: Stanford University P'ress, 1994.

HOLL, Bruce T. Don Quixote in Sologub's Melkij Bes. Slavic and East Earopean lournal. HUTCHEON, linda. Uma Teoria da Parodia, ensinamentos das formas de arte do século XX. Lisbod: Ldiçoes 70, 1985.

HUTCHINGS, Stephen C.. "Iedor Sologub's assthetics of natrative excess". In:

Russian Modernism. Cambridge: Cambridge University l'aess, 1997.

KHOIDASSIIVITCH, VI Nehropol Paris: YMCA I'RLSS, 1976.

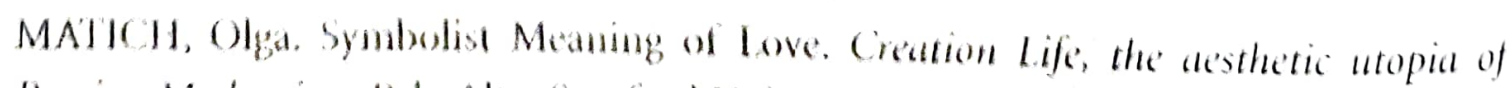
Russian Modernism. Palo Alto: Stanford University Press, 1094. 
MELETINSK1, E. M. Os arquétipos literários. São Paulo: Atelié Editorial, 2002.

PAVlova, Margarita. Pissátel-Inspiéktor, Fiódor Sologub i F. K. Tetiérnikov (Professor. -Inspetor, Fiodor Sologub c I. K. Tetićrnikov). Moscou: Novoe literaturnoe obozrente (Nova revista de literatura), 2007.

PORMORSKA, K. Formalismo e Futurismo. São Paulo: Perspectiva, 1972.

PÚCHKTN, Aleksándr. A Dama de Espadas. Tradução Boris Schnaiderman. São Paulo: Max Limonad Ltda., 1981.

RABINOWITZ, Stanley J. Sologub's Literary Children, keys to a simbolist's prose. Bloomington: Slavica Publishers, Inc., 1980.

SOLOGUB, Fiódor. O Diabo Mesquinho. Tradução Moissei Mountian. Săo Paulo: Kalinka, 2008.

ZAMIATIN, Evguéni. Litsa (Faces). Nova Iorque: Chekov Publishing House, 1955.

SCHNAIDERMAN, B. Dostoiévski através do tempo: "o romancista-filósofo", o público, a crítica. Turbilhâo e semente: ensaios sobre Dostoiêvskie Bakhtin. Săo Paulo: Duas Cidades, 1983.

TOLMATCHOV, Vassíli. Sobre as fronteiras do simbolismo. Tipologia to simbolismo nas culturas russa e ocidental. Sâo Paulo: Associaçīo Editorial Humantas, 2005. 